\title{
A STUDY ON THE WATER OCCUPANCY RATES OF KARACALAR DAM LAKE (SIVAS-TURKEY) IN THE PAST DECADE
}

\author{
Seher Dirican \\ Department of Crop and Animal Production, Sivas Technical Sciences \\ Vocational School, Sivas Cumhuriyet University - 58140, Sivas, Turkey. \\ DOI: https://doi.org/10.51193/IJAER.2021.7202
}

\begin{abstract}
Since the industrial revolution, greenhouse gases released into the atmosphere have increased. With increasing greenhouse gases, average air temperatures also increase, causing global climate change. The effects of climate change as well as the whole world is affected Turkey. Climate change increases the pressure on water resources. In this study, the water occupancy rates of Karacalar Dam Lake in Sivas province of Turkey were examined in the past decade. While the mean water occupancy rate of Karacalar Dam Lake in the past decade was 27.4 percent, the mean water occupancy rate in the past 6 years was determined to be 8.12 percent. Depending on these values, the effects of drought due to climate change were observed in Karacalar Dam Lake. Especially in the summer months, there is a significant decrease in the water occupancy rates of Karacalar Dam Lake. This can only be tackled with the correct water resources management.
\end{abstract}

Keywords: Karacalar Dam Lake, Sivas, Turkey

\section{INTRODUCTION}

The four indispensable factors in human life are water, air, sun and soil. Considering that water constitutes three quarters of our planet, the importance of water resources in our life can be understood better. Water must be met in the desired quality and quantity. Directing the water according to its purpose can only be achieved by dams. Dams are fixed structures that regulate the flow regime of the river and can provide a flow rate greater than the minimum flow in dry seasons. Dams, which were developed to meet the need for water at the requested time and serve to regulate the regime of streams, play an important role in the development of civilization. It is known by everyone that in the past, great civilizations have always been established on the water's edge and that water has an important place in development. Although there are sufficient water resources for the entire world population, their distribution over time and regions is not 
regular. While the amount of water needed for industrial, drinking and agricultural use increases, the available water supply in the world remains constant. Water resources must be operated sustainably. Dams, which ensure that variable water demands are met from reservoirs, are a part of civilization. In Turkey numerous dams are being built due to favorable hydrological and topographical structure. Although dams are expensive investments, they make great contributions to the country's economy [1]. Rapid population growth, technological developments and the increase in industrialization have brought many environmental problems. With this study, the water occupancy rates of the past decade of Karacalar Dam Lake in Sivas province were examined.

\section{MATERIAL AND METHOD}

Karacalar Dam Lake was built on the Karacalar Creek for agricultural irrigation between 1995 and 2008. Some of the main characteristics of the Karacalar Dam Lake are given in Table 1. The lake volume is $43.55 \mathrm{hm}^{3}$ at normal water elevation of the dam, which is an earth body fill type. Its height from the creek bed is $51 \mathrm{~m}$ and its lake area is $4.40 \mathrm{~km}^{2}$. Karacalar Dam Lake has a net agricultural irrigation area of 3690 hectares and the irrigation rate is $41 \%$ [2]. Karacalar Dam Lake is in Ulaş district of Sivas province and is approximately $40 \mathrm{~km}$ away from the city center.

Table 1: Some of the main characteristics of Karacalar Dam Lake.

\begin{tabular}{|l|c|}
\hline Year of Construction & 1995 \\
\hline Year of Operation & 2008 \\
\hline Goal of Dam & Agricultural Irrigation \\
\hline Creek & Karacalar Creek \\
\hline Body Fill Type & Soil \\
\hline Height & $51 \mathrm{~m}$ \\
\hline Lake Volume & $43.55 \mathrm{hm}^{3}$ \\
\hline Lake Area & $4.40 \mathrm{~km}^{2}$ \\
\hline Irrigation Area Gross & $4500 \mathrm{ha}$ \\
\hline
\end{tabular}

Ulaş district is in the south of Sivas central district and its average altitude from the sea is around 1390 meters. The climate of Ulaş district in the Central Anatolia Region of Turkey is continental. Summer months are hot and cool. The winter months are cold and snowy. The highest peak of the district's largest mountain, Tecer, is 3010 meters. The hottest months of the year are July and august. During these months the mean temperature is usually $+30{ }^{0} \mathrm{C}$. The coldest months are december and January. During these months when severe dry cold and southwester winds are effective, the temperature is around $-15{ }^{\circ} \mathrm{C}$, especially on some days. In winter, the night 
International Journal of Agriculture and Environmental Research

ISSN: 2455-6939

Volume: 07, Issue: 02 "March-April 2021"

temperature may decrease to $-35{ }^{\circ} \mathrm{C}$ below zero. After the harsh winter season, towards the end of February, the southeastern winds quickly melt the snow. The severity of cold weather is decreasing. Steppe is dominant in the general geographical structure of Ulaş district. There are a limited number of oak, poplar and willow trees in the district. The livelihood of the people is agriculture, animal husbandry and weaving. Ulaş district has rich wetland and wildlife assets. The most important river of Ulaş district is the Tecer Stream. Fish such as trout and carp live in the water of the Tecer Stream. In addition, the source of this stream is used as drinking water. There are 11 natural lakes in Ulaş district. Ulaş district lakes are an important breeding area for waterfowl. In the district, there are reeds and swamp lakes such as Tecer Lake, Alaçorak Lake and Kurugöl Lake. However, these lakes have suffered considerably due to seasonal droughts[2]. Karacalar Dam is an important agricultural irrigation lake for Ulaş district. This study was carried out for Karacalar Lake with the water occupancy rates of the past decade years between 2010-2019, which was obtained data from the General Directorate of State Hydraulic Works in Turkey. According to these data, the changes in the water occupancy rates of Karacalar Dam Lake in the past decade have been analyzed. In the light of the data obtained, important contributions for Karacalar Dam Lake are emphasized.

\section{RESULTS AND DISCUSSION}

The annual mean water occupancy rates and slope line of Karacalar Dam Lake according to the data of the past decade were given in Figure 1. Accordingly, the annual mean water occupancy rate in Karacalar Dam Lake was $48.63 \%$ in 2010, 48.28\% in 2011, 65.60\% in 2012, 62.80\% in 2013, 20.00\% in 2014, 9.50\% in 2015, 5.90\% in 2016, 0.00\% in 2017, 7.40\% in 2018 and 5.90\% in 2019 (Figure 1). The mean water occupancy rate of the Karacalar Dam Lake in the past decade has been calculated as $27.40 \pm 25$.93. Significant differences are observed between the water occupancy rates of the Karacalar Dam Lake in the past decade (Figure 1). It is observed that the water occupancy rates obtained in Karacalar Dam Lake were at high values in 2010, 2011, 2012 and 2013. However, low values are observed in 2014, 2015, 2016, 2017, 2018 and 2013. Accordingly, it is observed that the water occupancy rates of Karacalar Dam Lake have been at very low levels especially in the last 6 years. The slope line given in Figure 1 also confirms this decrease. According to the slope line given in Figure 1, it is observed that the water occupancy rates of Karacalar Dam Lake have been in a gradually decreasing trend in the past decade. The mean annual water occupancy rate of Karacalar Dam Lake between 2010 and 2013 was found to be $56.33 \pm 9.16$. On the other hand, between 2014 and 2019, the mean annual water occupancy rate of Karacalar Dam Lake was calculated as $8.12 \pm 6.62$. This indicates that the water occupancy rate of Karacalar Dam Lake has decreased considerably, especially in the last 6 years. The water level in Karacalar Dam Lake has been at low levels in recent years. It is observed that the decreases in the water occupancy rates in the 6-year period after 2013 in 
Karacalar Dam Lake are significant and their effect continues. Due to the decreases in these water occupancy rates, the waters of Karacalar Dam Lake have been withdrawn for meters and small islets have been formed on the dam surface. In some places, it has been observed that Karacalar Dam water has been withdrawn in summer about one kilometer especially in recent years. Local people have started to reuse some of the old agricultural lands that emerged after the withdrawal of Karacalar Dam water.

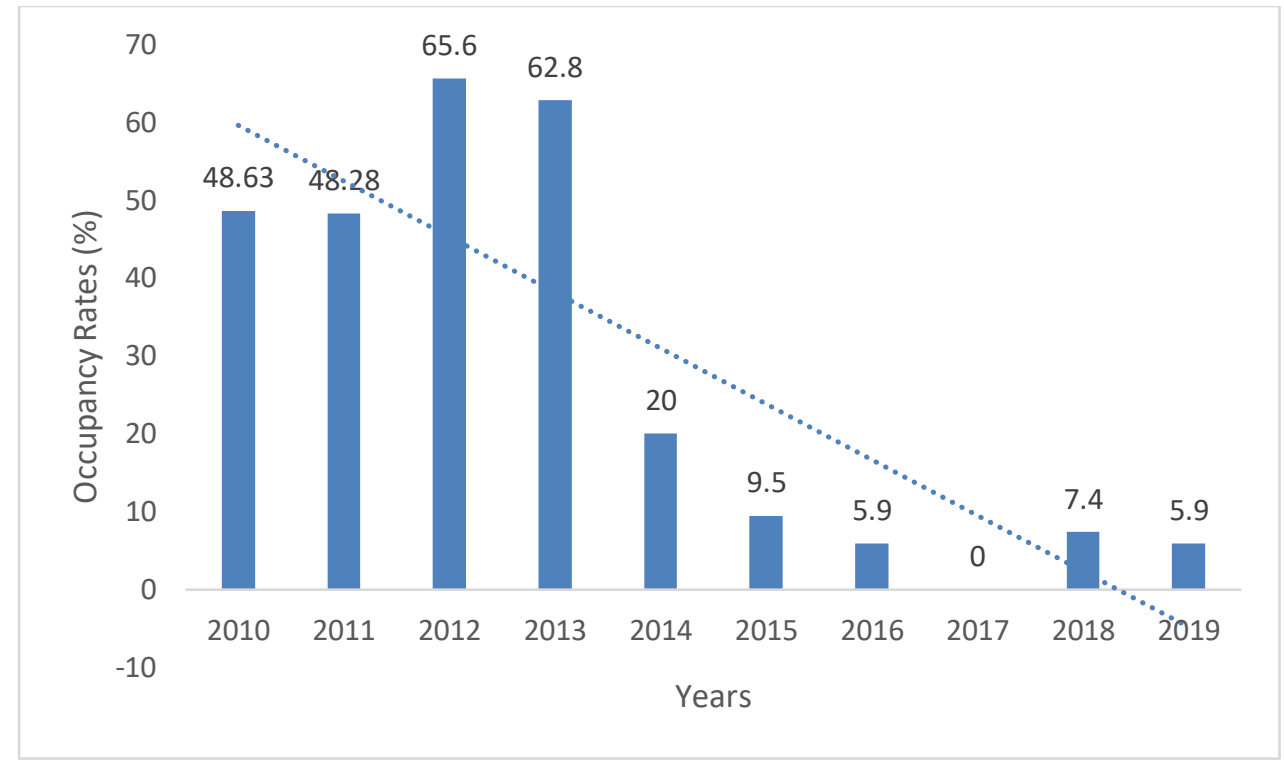

Figure 1: The mean water occupancy rates and slope line of Karacalar Dam Lake in the past decade.

Ulaş district of Sivas province where Karacalar Dam Lake is located is in the Upper Kızılırmak basin due to its geographical location. There is abundant gypsum in the territory of the Upper Kizilırmak basin. Gypsum dissolves easily. The excess amount of gypsum in the soil decreases the fertility of the soil. Animal husbandry has developed in Ulaş district due to the presence of large pastures. However, due to the large area of mountains and valleys, farming land is very scarce. For this reason, erosion has reached quite high levels with the destruction of forest areas over the years. In this case, it affects the decrease in the water occupancy rates of the Karacalar Dam Lake.

Climate change is an extremely complex problem, which is at the forefront of the most important environmental and economic problems of our age, and has negative effects in all areas of life, from health to agriculture. It is known that a series of global and regional effects of climate change emerged and these effects will increase day by day. The effects of climate change in Turkey; It manifests itself with the decrease in water resources, drought, hot air waves, increase 
International Journal of Agriculture and Environmental Research

ISSN: 2455-6939

Volume: 07, Issue: 02 "March-April 2021"

in floods and with decreasing productivity in agriculture[3]. Drought, whose impact is felt more and more every time due to climate change, is a meteorology-based environmental natural disaster that expresses the lack of water in a certain period [4]. As the duration of this natural event, which develops very slowly and occurs in a certain period, extends, its consequences reach very dangerous dimensions. It is observed that drought has begun to be felt with the unconscious use of water resources and the expected precipitation not occurring [5]. Sivas province, where Karacalar Dam Lake is located, was classified as arid by Cebeci [6] with a drought index value of 82.6. As a result of examining the water occupancy rates of the Karacalar Dam Lake in the past decade, it was determined that the mean value was $27.40 \%$. On the other hand, the mean water occupancy rate in the last 6 years has been determined as $8.12 \%$. This mean value indicates that the drought was quite effective in Karacalar Dam Lake between 20142019. It is predicted that this situation may cause serious problems not only in terms of environment but also in economic, social and cultural terms in Ulaş district of Sivas province where agricultural activities are actively carried out.

\section{CONCLUSION}

In Karacalar Dam, which is one of the important agricultural irrigation resources of the region, the mean water occupancy rate has decreased below the level of ten percent in the last 6 years. In Karacalar Dam Lake, it was observed that the regions where there was water before, are getting drier every year. As a result, the effective observation of the decrease in water occupancy rates in Karacalar Dam Lake in recent years gives an alarm at the point of complete drying. Many reasons such as global climate change, failure of expected precipitation, erosion and wrong water consumption have brought Karacalar Dam Lake to critical levels at the drying point. In this study, it was observed that the drought experienced in Karacalar Dam Lake in the past decade has changed in severity depending on many different factors. For Karacalar Dam Lake, which is a sustainable water resource, natural environment, green areas, forest areas should be protected and afforestation should be done. In the agricultural irrigation in Karacalar Dam Lake, where water use is the highest, innovative methods and devices should be used to save water.

\section{ACKNOWLEDGEMENTS}

Author thanks the Republic of Turkey General Directorate of State Hydraulic Works for sharing the water occupancy rate data regarding Karacalar Dam Lake.

\section{REFERENCES}

[1] Mehmet Berkün,"Water Structures (Dams, Weirs and Water Force Facilities),"Birsen Publishing House, İstanbul, Turkey, pp.667, 2007. 
[2] Sivas Province Environmental Status Report, "Sivas Province 2019 Environmental Status Report," Republic of Turkey, Sivas Governorship Provincial Directorate of Environment and Urban Planning, Environmental Impact Assessment and Environmental Permits Branch, Sivas, Turkey, pp.159, 2020.

[3] Emine Su Turan, "Turkey's Drought Status Associated with Climate Change,"Journal of Natural Hazards and Environment, 4(1), pp.63-69, DOI: 10.213247/dacd.357384, 2018.

[4] Emre Özelkan, Muhittin Karaman, "The Analysis of the Effect of Meteorological and Hydrological Drought on Dam Lake via Multitemporal Satellite Images: A Case Study in Atikhisar Dam Lake (Çanakkkale)," Ömer Halisdemir University Journal of Engineering Sciences, 7(2): pp.1023-1037, DOI: 10.28948/ngumuh.443230, 2018.

[5] Nur Sinem Partigöç, Sevde Soğanc1, "An Inevitable Consequence of Global Climate Change: Drought,"Resilience Journal 3(2),pp.287-299, DOI: 10.32569/resilience.619219, 2019.

[6] İlknur Cebeci, Oğuz Demirkıran, Orhan Doğan, Kevser Karagöz Sezer, Ödül Öztürk, Fatma Elbaş1, "Drought assessment of Turkey based on the provinces," Soil Water Journal, Special Issue, pp.169-176, 2019. 